\title{
KEARIFAN LOKAL DALAM CERITA RAKYAT LUBUKLINGGAU PROVINSI SUMATERA SELATAN
}

\section{LOCAL WISDOM OF LUBUKLINGGAU FOLKLORE IN SOUTH SUMATRA PROVINCE}

\author{
Hasanadi \\ Balai Pelestarian Nilai Budaya Sumatera Barat \\ Jl. Raya Belimbing No. 16 A, Kuranji, Padang \\ E-mail: hasanassyahda@yahoo.co.id
}

\begin{abstract}
Abstrak
Tulisan ini membicarakan refleksi kearifan lokal (local wisdom) dalam cerita rakyat Lubuk Linggau Provinsi Sumatera Selatan, yaitu cerita Linggau dan Dayang Torek: Asal Mula Kota Lubuk linggau, cerita Silampari: Mitos Kerajaan Ulak Lebar; dan cerita Bujang Kurap: Pengembara Sakti yang Budiman. Dengan menggunakan pendekatan hermeneutik disimpulkan bahwa setiap ungkapan memuat kearifan lokal (local wisdom) berupa nilai kebaikan serta kebijaksanaan masyarakat serta sebaliknya nilai keburukan, yang terefleksi melalui tema, penokohan serta amanat moral sosial-budaya masyarakat Lubuklinggau tempo dulu. Nilai kebaikan serta kebijaksanaan di antaranya, kesabaran, kesungguhan belajar, bertanggung jawab, membalas keburukan dengan kebaikan, serta mendahulukan kepentingan masyarakat dibandingkan kepentingan pribadi dan keluarga. Sementara itu, nilai keburukan yang mesti dihindarkan di antaranya, kesewenang-wenangan, egoisme, permufakatan jahat, dan emosional.
\end{abstract}

Kata kunci : Kearifan lokal, cerita rakyat, Lubuklinggau

\begin{abstract}
This paper discusses the reflection of local wisdom within Lubuklinggau folklore of South Sumatra Province, namely the story of Linggau and Dayang Torek: the Origin of Lubuklinggau City, the story of Silampari: the myth of the Ulak Lebar Kingdom, and the story of Bujang Kurap: Budiman, The Powerful Wanderer. By using hermeneutic approach, it is concluded that every expression contains local wisdom in the form of virtues and badness, reflected through theme, characterization and moral socio-culture mandate of Lubuklinggau community. The values of virtues are patience, learning determination, responsibility, responding evil with good deed, and prioritizing interests of society rather than personal and familial interests. Meanwhile, the evil attributes that must be avoided are arrogance, egoism, conspiracy in evil and uncontrolled emotion.
\end{abstract}

Keywords: Local wisdom, folklore, Lubuklinggau 


\section{PENDAHULUAN}

Objek kajian yang dibicarakan dalam tulisan ini cerita rakyat Lubuklinggau Provinsi Sumatera Selatan. Lubuklinggau adalah nama sebuah kota yang terletak pada posisi paling barat wilayah Provinsi Sumatera Selatan. Status "kota” untuk Lubuklinggau diberikan melalui UU No. 7 Tahun 2001 dan diresmikan pada 17 Agustus 2001. Kota Lubuklinggau merupakan pemekaran dari Kabupaten Musi Rawas, dan terletak pada posisi geografis yang sangat strategis, yaitu di antara Provinsi Jambi, Provinsi Bengkulu serta ibu kota Provinsi Sumatera Selatan (Palembang) dan merupakan jalur penghubung antara Pulau Jawa dengan kota-kota bagian utara Pulau Sumatera. Kota Lubuklinggau berdasarkan undang-undang no. 7 tahun 2001 memiliki luas 401,50 Km atau 40.150 Ha serta meliputi 8 wilayah kecamatan dan 2 kelurahan (Sumber : https://id.wikipedia.org/wiki/Kota_Lubuklinggau, diunduh tanggal 6 Maret 2016). Cerita rakyat Lubuklinggau, baik aspek "teks cerita" dan terutama berkenaan dengan "kearifan lokal" (local wisdom) yang terdapat dalam cerita, terkondisi menuju kepunahan. Dijelaskan oleh Bapak Darwis (Kepala Bidang Kebudayaan, Dinas Pariwisata Kota Lubuklinggau Provinsi Sumatera Selatan, wawancara tanggal 2 Maret 2017), beberapa cerita rakyat Lubuklinggau telah ditulis, khususnya cerita rakyat yang bergenre legenda. Namun demikian, sebagian besar cerita rakyat, khususnya dari genre mite dan dongeng, relatif tidak dikenal lagi oleh sebagian besar masyarakat, khususnya kalangan generasi muda. Masyarakat cenderung melupakan cerita rakyat yang didalamnya terekam berbagai peristiwa alam yang pernah terjadi di masa lalu, fenomena sejarah dan dinamika sosial kemanusian masyarakat Lubuklinggau zaman dahulu. Cerita-cerita tersebut dianggap sebatas produk masyarakat zaman dahulu yang selayaknya dilupakan, terutama karena sulit untuk dibuktikan kebenarannya oleh akal sehat dan keberadaannya dianggap tidak selaras dengan kehidupan di zaman sekarang. Konsekuensinya, setiap cerita tersebut hanya tersimpan dalam ingatan beberapa orang warga Lubuklinggau berusia lanjut serta tinggal menetap pada beberapa kelurahan di Kota Lubuklinggau.

Generasi muda Lubuklinggau, baik mereka yang tengah menimba ilmu pada berbagai jenjang pendidikan formal, maupun para anak muda putus sekolah serta bekerja pada berbagai bidang usaha, merasa asing dengan cerita rakyat. Generasi muda Lubuklinggau sekarang lebih tertarik pada berbagai cerita yang dengan mudah dapat mereka saksikan dengan memanfaatkan kecanggihan teknologi. Sebagaimana diakui oleh Bapak Suhariyoko (Kepala Bidang Pendidikan, Dinas Pendidikan dan Kebudayaan Kota Lubuklinggau Provinsi Sumatera Selatan, wawancara tanggal 2 Maret 2017), kenyataan memprihatinkan dalam konteks pelestarian cerita rakyat Lubuklinggau, terutama terkait dengan pewarisan kearifan lokal dalam cerita, disebabkan oleh 
beberapa faktor. Disamping pengaruh kemajuan ilmu pengetahuan dan teknologi, kurangnya minat anggota masyarakat di atas usia 60 tahun untuk bercerita ulang serta lemahnya keinginan generasi muda untuk berdiskusi seputar khasanah budaya masa lampau, masih minimnya sumber daya lokal, seperti ketersediaan akses, potensi dan sumber lokal yang unik dalam upaya pelestarian budaya yang dapat diketengahkan oleh pihak pemerintah daerah Lubuklinggau juga menjadi faktor penting yang tidak mungkin dilupakan (wawancara tanggal 2 Maret 2017).

Tokoh masyarakat Lubuklinggau, misalnya mereka yang bergelut dalam dunia akademik atau mereka yang eksis dikelembagaan adat, pun berada dalam pilihan yang dilematis. Pada satu sisi muncul keprihatinan serta kepedulian untuk ikut berperan dalam upaya pelestarian khasanah budaya masa lampau—khususnya cerita rakyat, sementara secara bersamaan mesti berhadapan dengan tantangan zaman yang didukung oleh kemajuan ilmu pengetahuan dan teknologi. Pada kondisi tersebut perhatian para tokoh masyarakat agaknya lebih berpihak pada berbagai persoalan sosial budaya yang lebih bersifat kekinian. Akibatnya, khasanah budaya masa lampau, semisal berbagai bentuk tradisi lokal, kesenian tradisional, dan dalam konteks kajian ini cerita rakyat, makin terasing serta terpinggirkan justru oleh masyarakat pemiliknya. Kalaupun tersisa maka yang akan disebut adalah "cerita rakyat" itu pernah ada namun semakin sulit untuk ditemukan anggota masyarakat yang mampu untuk menceritakan ulang.

Oleh karena itu, kajian terhadap cerita rakyat Lubuklinggau penting untuk dilakukan. Pertama, kajian bertajuk cerita rakyat Lubuklinggau menjadi langkah strategis dalam upaya melahirkan satu bentuk dokumentasi teks cerita rakyat Lubuklinggau, sehingga kehadirannya mampu menjadi bagian dari upaya antisipatif terkondisinya cerita rakyat tersebut berada dalam kepunahan. Kedua, terkait dengan perlunya pewarisan nilai-nilai kearifan lokal yang terdapat dalam setiap cerita rakyat Lubuklinggau kepada masyarakat, khususnya kepada generasi muda. Masyarakat dan generasi muda Lubuklinggau perlu menemukenali berbagai bentuk pengetahuan serta kebijaksanaan-kebijaksanaan (kearifan lokal) masyarakat masa lampau, sebagaimana terdapat dalam cerita rakyat, dalam upaya penguatan karakter di masa sekarang. Setiap upaya yang dilakukan dalam rangka menemukenali kearifan lokal cerita rakyat tersebut pada gilirannya akan memunculkan sikap dan perilaku budaya yang tetap berterima dalam konteks zaman yang tengah dihadapi.

Pewarisan kearifan lokal dalam cerita rakyat Lubuklinggau berhadapan dengan berbagai kendala dan tentangan kehidupan di masa sekarang. Sementara itu, sikap serta perilaku masyarakat yang mengidealisasi nilai-nilai kearifan lokal dalam cerita rakyat, dinilai mampu 
menguatkan munculnya gagasan dan pengetahuan baru. Sikap dan perilaku tersebut dianggap mampu mewarnai aktifitas sosial kemasyarakatan yang mengindikasikan berintegrasinya nilainilai budaya masa lampau dengan tuntutan zaman di masa sekarang. Sekaligus, sikap dan perilaku tersebut akan menjadi basis sosial dalam proses penciptaan benda-benda budaya yang bermanfaat dalam berbagai aspek kehidupan. Oleh karena itu, tulisan ini berupaya menjawab pertanyaan, bagaimana refleksi kearifan lokal dalam cerita rakyat Lubuklinggau Provinsi Sumatera Selatan?

\section{METODE PENELITIAN}

Branvand mengelompokkan cerita rakyat ke dalam folklor, khususnya folklor lisan. Istilah folklor sendiri berasal dari kata folklore (Inggris) dan dibentuk dari dua kata, yaitu folk dan lore. Folk adalah sekelompok orang yang memiliki ciri-ciri pengenal fisik, sosial dan kebudayaan, sehingga dapat dibedakan dari kelompok-kelompok kebudayaan yang lain. Ciri-ciri pengenal tersebut dapat berupa warna kulit yang sama, bentuk rambut yang sama, mata pencarian yang sama, bahasa yang sama, taraf pendidikan yang sama, dan agama yang sama. Namun demikian, yang lebih penting lagi adalah bahwa mereka telah memiliki suatu tradisi, yaitu kebudayaan yang telah mereka warisi secara turun-temurun, sedikitnya dua generasi yang dapat mereka akui sebagai milik bersama. Di samping itu, yang paling penting adalah, bahwa mereka sadar dengan identitas kelompok mereka. Sementara itu, lore adalah tradisi folk, yaitu sebagian kebudayaannya, yang diwariskan secara turun temurun secara lisan, atau melalui suatu contoh yang disertai dengan gerak isyarat atau alat pembantu pengingat (mnemonic device). Jadi, folklor adalah sebagian kebudayaan suatu kolektif yang tersebar dan diwariskan secara turun temurun diantara kolektif macam apa saja, secara tradisional dalam versi yang berbeda, baik dalam bentuk lisan, maupun contoh yang disertai dengan gerak isyarat atau alat pembantu pengingat (Danandjaja, 1984).

Disamping cerita rakyat yang terkelompok ke dalam mite, legenda dan dongeng, folkor lisan meliputi: (1) Bahasa rakyat, seperti julukan tradisional; (2) Ungkapan tradisional seperti pribahasa; (3) Pertanyaan tradisional, seperti teka-teki; (4) Puisi rakyat, seperti gurindam dan pantun; dan (6) Nyanyian rakyat. Mite adalah cerita rakyat yang dianggap benar-benar terjadi dan dianggap suci oleh pemilik cerita. Peristiwa yang terjadi dalam mite terjadi di diunia lain, bukan di dunia yang kita kenal sekarang dan terjadi pada masa lampau. Pemerannya adalah dewa atau manusia setengah dewa. Legenda adalah cerita rakyat yang memiliki ciri-ciri seperti mite, yakni dianggap benar-benar terjadi tetapi tidak dianggap suci oleh pemilik cerita. Tempat terjadinya adalah di dunia yang kita kenal ini dan waktu terjadinya belum terlalu lampau. Pemeran 
dalam legenda adalah manusia yang memiliki sifat luar biasa dan kadang kala dibantu oleh makhluk ghaib. Legenda terklasifikasi ke dalam empat kelompok, yaitu :

1. Legenda keagamaan (lerigious legend), yaitu legenda orang-orasang suci (saints) nasrani. Dengan pengertian demikian, ketika legenda ini telah diakui dan disahkan oleh gereja katolik Roma akan menjadi bagian dari kesusastraan agama yang disebut hagiografhy (legends of the saints), yang berarti tulisan, karangan, atau buku mengenai kehidupan orang-orang saleh.

2. Legenda alam gaib (supranatural legend), yaitu legenda yang berisikan kisah yang dianggap benar-benar terjadi dan pernah dialami seseorang. Fungsi legenda semacam ini adalah untuk mengukuhkan kebenaran takhayul atau kepercayaan rakyat.

3. Legenda perseorangan (personal legend), yaitu legenda yang berisikan cerita mengenai tokoh-tokoh tertentu yang dianggap oleh pemilik cerita pernah benar-benar terjadi.

4. Legenda setempat (local legend), yaitu legenda yang berhubungan dengan cerita suatu tempat, nama tempat, bentuk topografi berupa bentuk permukaan suatu daerah (Danandjaja, 1991).

Dongeng adalah cerita rakyat yang tidak dianggap benar-benar terjadi dan tidak terikat oleh ruang dan waktu. Anti Aarne dan Stith Thomson juga mengelompokkan dongeng ke dalam empat kelompok besar, yaitu sebagai berikut :

1. Dongeng binatang (animal tales), dongeng biasa (ordinary folktales), lelucon dan anekdot (jokes and anecdotes), dan dongeng berumus (formula tales). Dongeng binatang adalah dongeng yang ditokohi oleh binatang peliharaan dan binatang liar, seperti binatang menyusui, burung, binatang melata (reptilia), ikan dan serangga. Binatang-binatang dalam dongeng ini dipercayai dapat berbicara dan berakal budi sebagaimana manusia.

2. Dongeng biasa, yaitu dongeng yang ditokohi manusia dan biasanya adalah kisah suka duka seseorang. Lelucon dan anekdot adalah dongeng-dongeng yang dapat menimbulkan rasa menggelikan hati sehingga dapat menimbulkan ketawa bagi yang mendengarnya maupun bagi yang menceritakannya, walaupun, bagi kelompok tertentu, dongeng ini dapat menimbulkan rasa sakit hati. Terakhir, dongeng berumus disebut juga formula tales, disebabkan strukturnya yang mengalami pengulangan. 
Cerita rakyat sebagai bagian dari kearifan lokal dalam perspektif budaya lebih ditekankan sebagai nilai yang diciptakan, dikembangkan dan dipertahankan masyarakat dan karena kemampuannya masyarakat tersebut mampu bertahan serta menjadikan kearifan lokal tersebut sebagai pedoman. Di dalam kearifan lokal terdapat berbagai mekanisme dan cara untuk bersikap, berperilaku, dan bertindak yang dituangkan dalam suatu tata sosial. Pada dasarnya terdapat lima dimensi kultural tentang kearifan lokal, yaitu pengetahuan lokal, budaya lokal, keterampilan lokal, sumber daya lokal, dan proses sosial lokal. Pengetahuan lokal bertautan dengan data dan informasi tentang karakter keunikan lokal serta pengetahuan dan pengalaman masyarakat dalam menghadapi masalah serta solusinya. Budaya lokal terkait dengan unsur-unsur kebudayaan yang telah terpola dan dijadikan sebagai tradisi. Keterampilan lokal berkaitan dengan keahlian masyarakat untuk memanfaatkan pengetahuan yang diperoleh. Sumberdaya lokal berkenaan dengan ketersediaan akses, potensi dan sumber lokal yang unik. Proses sosial lokal berbicara tentang bagaimanakah masyarakat tertentu menjalankan fungsi-fungsinya, sistem tindakan sosial yang dilakukan, tata hubungan sosial di antara mereka, alat yang digunakan serta kontrol sosial yang dilakukan (Sibarani, 2016: 437).

Tulisan ini diramu ulang berdasarkan hasil penelitian yang bersifat kualitatif. Penelitian kualitatif adalah penelitian yang bermaksud memahami fenomena tentang apa yang dialami subjek penelitian misalnya perilaku, persepsi, motivasi, tindakan, dan lain-lain, secara holistik dan dengan cara deskriptif dalam bentuk kata-kata dan bahasa, pada suatu konteks khusus yang alamiah dan dengan memanfaatkan berbagai metode ilmiah (Maleong, 2009: 6). Penelitian kualitatif menekankan quality atau hal terpenting dari sifat suatu barang/jasa. Hal terpenting dari suatu barang atau jasa berupa kejadian/fenomena/gejala sosial adalah makna dibalik kejadian tersebut yang dapat dijadikan pelajaran berharga bagi pengembangan konsep teori. Jangan sampai sesuatu yang berharga tersebut berlalu tanpa meninggalkan manfaat. Penelitian kualitatif diekplorasi dan diperdalam dari suatu fenomena sosial atau suatu lingkungan sosial yang terdiri atas perilaku, kejadian, tempat dan waktu (Satori dkk, 2009: 22). Proses pengumpulan data penelitian serta pengolahan data dan informasi dilakukan dalam beberapa teknik, yaitu observasi, wawancara, rekam, studi kepustakaan, dan analisis data. Setelah melakukan observasi, wawancara, perekaman, maka data primer berupa teks cerita rakyat dianalisis dengan menggunakan pendekatan hermeneutik.

Secara etimologis, hermeneutik berasal dari kata hermeneuein, bahasa Yunani, yang berarti menafsirkan atau menginterpretasikan. Secara mitologis, pendekatan ini dikaitkan dengan dengan Hermes, nama Dewa Yunani yang menyampaikan pesan Illahi kepada manusia. Pada 
dasarnya media pesan adalah bahasa, baik bahasa lisan maupun bahasa tulisan. Jadi, penafsiran disampaikan lewat bahasa, bukan bahasa itu sendiri. Teks sastra perlu ditafsirkan sebab di satu pihak ia terdiri atas bahasa, dipihak lain, di dalam bahasa sangat banyak makna yang tersembunyi, atau dengan sengaja disembunyikan (Ratna, 2004: 45). Hermeneutik berkaitan dengan upaya pemaknaan suatu analog teks; misalnya memahami organisasi atau kelompok sosial melalui pemaknaan cara lisan atau data tekstual. Pertanyaan mendasar adalah : apa arti dan makna teks itu ? Ini berarti, interpretasi adalah upaya untuk membuat jelas atau membuat studi bermakna. Oleh sebab itu, objek mesti kajian mesti dalam bentuk teks atau analog teks yang sepintas terlihat kabur serta terkadang saling bertentangan. Interpretasi bermaksud agar yang tidak jelas menjadi jelas untuk bisa dipahami. Interpretasi mesti menjadi kerangka berfikir dalam usaha memperjelas pengertian tersembunyi menjadi sesuatu yang bermakna dan jelas (Maleong, 1989: 2).

Pendekatan hermeneutik memandang teks sastra dan filsafat sebagai objek kajian yang seyogianya disejajarkan dengan pendekatan interpretasi, pemahaman, versthen dan retroaktif. Dalam ilmu-ilmu sosial juga disebut metode kualitatif, analisis isi, alamiah, naturalistik, studi kasus, etnografi, etnometodologi dan fenomenologi serta biasanya dipertentangkan dengan metode kuantitatif (Maleong, 1989). Selanjutnya, pendekatan hermeneutik dipandang tepat untuk digunakan dalam menganalisis teks cerita rakyat yang dimiliki secara kolektif oleh masyarakat Lubuklinggau. Namun demikian, penggunaan hermeneutik tidak dimaksudkan untuk menghasilkan interpretasi yang bersifat paling tepat dan benar. Kenyataan tersebut didasarkan kenyataan bahwa setiap subyek peneliti dimungkinkan untuk memiliki titik berpijak yang berbeda. Penafsiran berbeda adalah suatu keniscayaan, karena setiap subjek akan memandang objek melalui horoson dan paradigma yang berbeda.

\section{PEMBAHASAN}

\section{Selayang Pandang Kota Lubuklinggau}

Tahun 1929 status Lubuklinggau adalah ibu kota Marga Sindang Kelingi Ilir, di bawah Onder District Musi Ulu. Onder District Musi Ulu sendiri ibu kotanya adalah Muara Beliti.Tahun 1933 ibukota Onder District Musi Ulu dipindah dari Muara Beliti ke Lubuklinggau. Tahun 1942-1945 Lubuklinggau menjadi ibukota Kewedanaan Musi Ulu dan dilanjutkan setelah kemerdekaan. Pada waktu Clash I tahun 1947 Lubuklinggau dijadikan Ibukota Pemerintahan Provinsi Sumatera bagian Selatan. Tahun 1948 Lubuklinggau menjadi ibukota Kabupaten Musi 
Ulu Rawas dan tetap sebagai ibukota Keresidenan Palembang (BPS Kota Lubuklinggau Provinsi Sumatera Selatan tahun 2015).

Pada tahun 1956 Lubuklinggau menjadi ibukota Daerah Swatantra Tingkat II Musi Rawas. Tahun 1981 dengan Peraturan Pemerintah Republik Indonesia Nomor 38 tanggal 30 Oktober 1981 Lubuklinggau ditetapkan statusnya sebagai Kota Administratif. Tahun 2001 dengan Undang-Undang Republik Indonesia Nomor 7 tahun 2001 tanggal 21 Juni 2001 Lubuklinggau statusnya ditingkatkan menjadi Kota. Pada tanggal 17 Oktober 2001 Kota Lubuklinggau diresmikan menjadi daerah otonom.

Pembangunan Kota Lubuklinggau telah berjalan dengan pesat seiring dengan segala permasalahan yang dihadapinya dan menuntut ditetapkannya langkah-langkah yang dapat mengantisipasi perkembangan Kota, sekaligus memecahkan permasalahan-permasalahan yang dihadapi. Untuk itu diperlukan Manajemen Strategis yang diharapkan dapat mengelola dan mengembangkan Kota Lubuklinggau sebagai kota transit ke arah yang lebih maju menuju kota metropolitan. Kota Lubuklinggau terletak pada posisi geografis yang sangat strategis yaitu di antara Provinsi Jambi, Provinsi Bengkulu serta ibu kota Provinsi Sumatera Selatan (Palembang) dan merupakan jalur penghubung antara Pulau Jawa dengan kota-kota bagian utara Pulau Sumatera.

Luas wilayah Kota Lubuklinggau berdasarkan undang-undang No. 7 tahun 2001 seluas 401,50 Km atau 40.150 Ha, yang meliputi 8 wilayah kecamatan dan 72 kelurahan. Kota Lubuklinggau adalah suatu kota setingkat kabupaten, terletak paling barat wilayah Provinsi Sumatera Selatan serta terletak pada posisi antara $102^{\circ} 40^{\prime} 0^{\prime \prime}-103^{\circ} 00^{\prime} 0$ " Bujur Timur dan $3^{\circ}$ 4' 10" - $3^{\circ} 22^{\prime} 30^{\prime \prime}$ Lintang Selatan, berbatasan langsung dengan Kabupaten Rejang Lebong Provinsi Bengkulu yang secara administratif mempunyai batas-batas sebagai berikut :

- Sebelah Utara : Berbatasan dengan Kecamatan BKL Ulu Terawas Kabupaten Musi Rawas.

- Sebelah Timur : Berbatasan dengan Kecamatan Tugu Mulyo dan Muara Beliti Kabupaten Musi Rawas.

- Sebelah selatan : Berbatasan dengan Kecamatan Muara Beliti dan Provinsi Bengkulu.

- Sebelah barat : Berbatasan dengan Kabupaten Rejang Lebong Provinsi Bengkulu

Pada tahun 2013 Pemerintah Kota Lubuklinggau membuat program VISIT Lubuklinggau 2015, yaitu dalam rangka meningkatkan kepariwisataan Kota Lubuklinggau. Beberapa tempat wisata yang ada di Kota Lubuklinggau sebagai berikut: 
1. Bukit Sulap, yang letaknya sekitar $2 \mathrm{~km}$ dari pusat kota diresmikan oleh Gubernur Sumatera Selatan, H.Alex Noerdin pada tahun 2014. Tempat wisata ini sudah dilengkapi toko-toko dan warung-warung. Bukit Sulap akan dilengkapi oleh inclinator yang akan selesai pada tahun 2016.

2. Air Terjun Temam atau disebut juga "Niagara Lubuklinggau", yang letaknya sekitar $8 \mathrm{Km}$ sudah dilengkapi toko-toko dan warung-warung. Tempat wisata ini juga dilengkapi dengan yang dibangun oleh PT Linggau Bisa. Pada malam hari Air Terjun Temam akan terlihat lebih bagus karena dilengkapi dengan lampu sorot.

3. Masjid Agung As Salam, merupakan masjid terbesar di Kota Lubuklinggau. Masjid ini sedang direnovasi oleh pemerintah sejak tahun 2013 dalam menyambut Visit Lubuklinggau 2015. Masjid ini dilengkapi dengan Taman Kurma (eks Lapangan Merdeka) yang pohon kurmanya didatangkan langsung dari Arab. Masjid ini dilengkapi juga dengan air mancur menari-nari yang akan menari setiap adzan, serta nantinya dilengkapi juga menara kapsul.

4. Museum Subkoss Garuda, terletak di dekat Masjid Agung As Salam, berisi peninggalanpeninggalan di Lubuklinggau. Peninggalan-peninggalan di museum kebanyakan alat-alat saat perang kemerdekaan.

\section{Refleksi Kearifan Lokal Cerita Rakyat Lubuklinggau}

Cerita rakyat Lubuklinggau yang dibicarakan dalam tulisan ini adalah cerita Linggau dan Dayang Torek : Asal Mula Kota Lubuklinggau, cerita Silampari : Mitos Kerajaan Ulak Lebar, dan cerita Bujang Kurap : Pengembara Sakti yang Budiman. Berikut ini disajikan dokumentasi teks cerita sekaligus penjelasan tentang kearifan lokal (local widom) masyarakat Lubuklinggau yang direfleksikan oleh masing-masing cerita.

\section{Linggau dan Dayang Torek : Asal Mula Kota Lubuklinggau}

Alkisah pada zaman kerajaan, Lubuklinggau banyak melahirkan para pendekar yang memiliki ilmu kesaktian tinggi. Pada masa itu, siapa yang paling tinggi ilmu kesaktiannya maka dialah yang berkuasa. Kemampuan ilmu beladiri yang mumpuni serta keterampilan dalam memperbuat hal-hal yang berada di luar akal sehat manusia merupakan ukuran penting sehingga seseorang dihargai ditengah masyarakat. Karenanya, salah satu tujuan hidup di masa itu adalah, menguasai berbagai ilmu kesaktian, meskipun untuk mendapatkannya seseorang harus melalui 
berbagai rintangan serta marabahaya yang mengancam nyawa. Seseorang dikala itu tidak akan berhenti mencari ilmu kesaktian sebelum dia tersohor keberbagai pelosok karena kesaktian yang dimiliki.

Tersebutlah Linggau, putra mahkota kerajaan, sekaligus tokoh penting legenda lokal Lubuklinggau ini. Linggau adalah putra kesayangan baginda, seorang raja yang dikenal arif serta bijaksana di seantero negeri. Linggau adalah tumpuan harapan istana, penerus serta pewaris kejayaan kerajaan di masa depan. Di luar istana, rakyat kerajaan di lembah Bukit Sulap tersebut hidup damai dan sejahtera. Mereka mencukupi seluruh kebutuhan hidup dengan mengolah serta memanfaatkan berbagai hasil yang telah disediakan oleh alam. Rakyat menjalani kehidupan dengan penuh suka cita serta senantiasa merasa dinaungi oleh keluarga istana. Apalagi, raja mereka terkenal sakti mandraguna. Kesaktian baginda raja tidak hanya dikenal didalam lingkungan kerajaan, melainkan juga ditakuti oleh para pendekar sakti yang hidup di masa itu, terutama oleh para penjahat dan perampok.

Linggau dikenal mempunyai berbagai ilmu ketangkasan dan kesaktian. Sedari kecil dia telah mewarisi kesaktian sang raja serta menimba ilmu ke berbagai guru yang mumpuni. Linggau terus bertumbuh menjadi remaja yang memiliki kepribadian mulia. Wajah rupawan menjadikan Linggau sagat disayangi oleh seluruh anggota kerajaan serta senantiasa menjadi buah bibir masyarakat. Banyak para gadis di kerajaan yang mendambakan menjadi pendamping hidupnya. Sayang seribu kali sayang, Linggau belum bermaksud menjatuhkan pilihannya pada seorang gadis. Sebagai pewaris tahta Linggau menyadari tugas serta tanggung jawabnya kelak. Karena itu, yang terpenting bukanlah segera menikah serta menjalani kehidupan berumah tangga. Tugasnya sekarang mengumpulkan banyak bekal pengetahuan sebagai calon pewaris tahta kerajaan. Berilmu tinggi, baik ilmu kesaktian, maupun ilmu tentang pemerintahan.

Pilihan hidup tidak segera mempersunting seorang gadis menjadikan Linggau dijuluki "bujang tua". Namun demikian, julukan tersebut tidaklah menjadikan Linggau surut dari keputusan yang diambil. Dia tetap dengan sikapnya, menimba banyak pengalaman serta memilih untuk tidak segera menikah. Apalagi, dia memiliki Dayang Torek, adik perempuannya yang cantik jelita. Kecantikan Dayang Torek tersebar sampai ke kerajaan tetangga. Linggau sangat menyayangi Dayang Torek. Dia sadar bahwa Dayang Torek adalah incaran setiap pemuda di kerajaan bahkan oleh mereka yang berasal dari kerajaan tetangga tersebut. Karena itu, tanggung jawabnya adalah melindungi Dayang Torek. Linggau tidak mencemaskan setiap pemuda yang ada di kerajaan. Sebaliknya, gelagat kurang baik justru muncul dari para raja dan pengeran 
sakti yang berasal dari kerajaan tetangga. Mereka mengincar Dayang Torek dan tentunya akan menempuh segala cara untuk dapat mempersuntingnya.

Kecantikan Dayang Torek terdengar oleh seorang pendekar sakti yang bernama Si Pahit Lidah. Sesuai dengan namanya, Si Pahit Lidah memiliki sumpah yang sakti. Perkataan Si Pahit Lidah adalah kenyataan pahit bagi setiap yang mendengarnya. Siapa yang tidak suka akan merasakan akibat dari sumpah sakti Si Pahit Lidah. Linggau makin mengkhawatirkan keselamatan Dayang Torek yang ternyata tidak menyenangi Si Pahit Lidah. Si Pahit Lidah berkeinginan mempersuntingnya dan seluruh anggota kelurga kerajaan tidak merestui. Untuk menghindari Si Pahit Lidah, Linggau pun menyembunyikan Dayang Torek di dasar sungai. Linggau sengaja membuat sebuah lubuk yang dalam dengan menancapkan taring giginya ke dasar sungai. Disitulah Dayang Torek bersembunyi. Dayang Torek selamat dari incaran Si Pahit Lidah. Bukan hanya itu, tidak seorang pun mengetahui keberadaan lubuk persembunyian Dayang Torek.

Masyarakat Lubuklinggau percaya bahwa dari banyaknya lubuk yang terdapat di sungai Lubuklinggau, lubuk yang konon menjadi tempat persembunyian Dayang Torek pada zaman dahulu adalah keramat serta memiliki keanehan. Lubuk itu kecil namun sangat dalam. Sampai sekarang lubuk itu dianggap sakti serta kemudian ditakuti. Masyarakat percaya bahwa dalam setiap tahun lubuk tersebut akan memakan korban. Mereka adalah para gadis berwajah cantik yang akan menemani Dayang Torek dalam persembunyiannya.

Karena yang membuat lubuk tersebut adalah Linggau maka lubuk tersebut dinamakan "Lubuklinggau”. Lubuk itu berada tepat di bawah jembatan yang terletak di Dusun Linggau Kelurahan Linggau Kecamatan Lubuklinggau Barat I. Lubuk tersebut kecil dan dalam serta air di atasnya sangat tenang. Tidak pernah ada batu yang menutupi lubuk tersebut. Pada zaman dahulu daerah di sekitar Lubuk tersebut dikenal dengan nama Dusun Linggau. Sekarang, menjadi nama sebuah kota, Kota Lubuklinggau.

\section{Refleksi Kearifan Lokal}

"Di luar istana, rakyat kerajaan di lembah Bukit Sulap tersebut hidup sejahtera. Mereka mencukupi seluruh kebutuhan hidup dengan mengolah serta memanfaatkan berbagai hasil yang telah disediakan oleh alam". 
Pesan budaya yang penting ditulis untuk cerita "Linggau dan Dayang Torek: Asal Mula Kota Lubuklinggau”, sebagaimana tersirat melalui teks di atas adalah pentingnya sikap berempati terhadap lingkungan. Masyarakat kerajaan memiliki kesadaran sekaligus empati yang kuat terhadap lingkungan, yaitu melihat alam kerajaan sebagai potensi yang mesti diolah serta dimanfaatkan sebaik mungkin. Mereka bersedia mengolah serta memanfaatan sumber daya alam yang ada. Mereka memilih untuk berdiam di kampung halaman serta eksis di tanah kelahiran sendiri. Sebagaimana dijelaskan Suhariyoko, ketersediaan sumber daya alam menjadi penting bagi penopang kesejahteraan masyarakat di suatu daerah. Untuk konteks Lubuklinggau, lebih penting lagi adalah kuatnya komitmen, kesediaan serta kesungguhan masyarakat dengan dorongan serta sokongan dari pemerintah daerah untuk menata kehidupan dengan jalan mengolah lahan serta memanfaatkan sumber daya alam yang ada. Komitmen sadar lingkungan itu sekaligus menjadi bukti bakti masyarakat Lubuklinggau, terutama di masa kerajaan sebagaimana diisyaratkan dalam teks cerita terhadap kampung halaman (wawancara tanggal 2 Maret 2017).

Warisan kearifan lokal dalam bentuk pilihan sikap serta perilaku yang sadar lingkungan penting ditumbuhkan masyarakat Lubuklinggau di masa sekarang. Pilihan untuk berdiam di kampung halaman serta bersedia untuk mengolah sumber daya alam yang tersedia, tentunya tetap menjadi pilihan yang menjanjikan kesejahteraan. Lubuklinggau relatif kaya dengan sumberdaya alam yang menantikan garapan tangan-tangan kreatif masyarakatnya. Generasi muda Lubuklinggau perlu membuktikan bahwa mereka bisa berbuat banyak dengan menggali segala potensi yang ada di bumi Lubuklinggau. Tanggung jawab terhadap tanah kelahiran perlu dimiliki oleh generasi muda Lubuklinggau, sehingga tidak serta merta meninggalkan kampung halaman karena lebih tergiur oleh kehidupan rantau. Kalaupun harus keluar dari kampung halaman, misalnya untuk kepentingan menuntut ilmu, maka "pulang kampung" merupakan pilihan bijak yang mesti diambil. Sadar lingkungan menjadi penting terutama sebagai spirit usia muda menyongsong hari tua yang sejahtera. Sadar lingkungan, yaitu sebagai karakter yang diwariskan, merupakan modal yang mesti terus diasah guna melahirkan generasi pembaruan Lubuklinggau di masa sekarang.

Cinta ilmu pengetahuan—dalam konteks cerita "Linggau dan Dayang Torek : Asal Mula Kota Lubuklinggau" disebut ilmu kesaktian, merupakan kearifan lokal Lubuklinggau di zaman kerajaan yang perlu diwarisi. Kesungguhan, kesabaran serta perjuangan Linggau dalam menuntut ilmu kesaktian serta menimba pengalaman yang dibutuhkan oleh zaman ketika ia hidup, merupakan tipikal perilaku yang mesti dimiliki oleh generasi muda Lubuklinggau di masa sekarang. Digambarkan dalam cerita, Linggau mengabaikan kepentingan pribadinya yang lain, 
misalnya menolak untuk segera menikah karena kecintaannya yang besar terhadap ilmu kesaktian. Linggau terus memantapkan tujuan hidup yang menurutnya lebih mulia, yaitu sakti mandraguna (berilmu pengetahuan luas). Linggau memilih untuk mengabdikan hidupnya di jalan ilmu serta menolak untuk segera menikah meskipun pada akhirnya dijuluki “bujang tua”.

Menurut Linggau, ilmu kesaktian merupakan syarat penting yang mesti dimiliki guna meraih berbagai kemudahan seta kesuksesan dalam hidup, meskipun harus diraih dengan menempuh berbagai rintangan. Linggau senantiasa menyempatkan diri untuk belajar sesuatu yang baru atau menyempurnakan kesaktian yang telah dimiliki, yaitu sebagai bekal hidup yang lebih memberikan makna. Lebih penting lagi, pilihan Linggau tidak hanya untuk kepentingan pribadinya namun juga untuk kepentingan zamannya. Semangat serta kecintaan terhadap ilmu kesaktian itulah yang mesti diwarisi oleh masyarakat Lubuklinggau, terutama oleh generasi muda. Kebutuhan zaman terus berubah, termasuk dalam konteks ilmu pengetahuan dan keterampilan, namun kecintaan terhadap ilmu tetaplah spirit zaman yang tetap harus dipelihara serta dipupuk oleh generasi muda Lubuklinggau.

Kearifan lokal dalam cerita juga mengisyarat melalui tipikal santun, sederhana serta peduli dengan kepentingan masyarakat kalangan bawah yang ditunjukkan oleh anggota keluarga kerajaan. Tipikal keluarga istana itu pula yang kemudian memunculkan rasa cinta, hormat dan patuh dari para warga kepada pemimpin mereka. Anggota keluarga istana mampu menjadi figur pemimpin yang patut ditauladani dalam bersikap dan bertindak. Rakyat kerajaan merasa dekat secara emosional dengan anggota keluarga istana. Mereka merasa diperhatikan dan percaya bahwa istana berpihak pada kepentingan-kepentingan mereka selaku rakyat jelata. Kondisi itu tentunya penting untuk diidealisasi dalam konteks sosial pemerintahan masyarakat Lubuklinggau di masa sekarang. Kepedulian dan empati aparatur pemerintah daerah Kota Lubuklinggau terhadap masyarakat merupakan jembatan hati yang pada gilirannya akan sangat membantu upaya mensukseskan berbagai kebijakan pembangunan. Sebaliknya, serta rasa hormat dan patuh yang ditunjukkan oleh anggota masyarakat kepada aparatur pemerintah, tentunya akan melahirkan kepedulian untuk ikut berpartisipasi aktif dalam kegiatan-kegitan pembangunan yang dimotori oleh pemerintah daerah.

Cuplikan cerita tentang keluarga istana di zaman Linggau dan Dayang Torek hidup mengajak aparatur Pemerintah Daerah Kota Lubuklinggau mampu mencontohkan pola hidup sederhana serta jauh dari gaya hidup penuh kemewahan. Karena itu pula, berbagai fasilitas pemerintah yang tersedia mesti digunakan untuk kepentingan rakyat, bukan untuk kepentingan pribadi aparatur pemerintah semata. Di lain pihak, pemerataan pembangunan merupakan 
kebutuhan dasar masyarakat yang harus mampu diwujudkan oleh Pemerintah Daerah Kota Lubuklinggau. Masyarakat Lubuklinggau secara keseluruhan perlu mengenyam manisnya keberhasilan pembangunan yang dicanangkan oleh pihak pemerintah Kota Lubuklinggau. Akhirnya, keharusan demi keharusan tersebut, sebagai karakter aparatur pemerintah sekaligus warisan kearifan lokal cerita "Linggau dan Dayang Torek : Asal Mula Kota Lubuklinggau" menjadi spirit dalam usaha mensejahterakan masyarakat Kota Lubuklinggau.

Bertanggung jawab juga menjadi kearifan lokal cerita "Linggau dan Dayang Torek : Asal Mula Kota Lubuklinggau". Sebagaimana dicontohkan oleh Linggau dalam menjaga serta melindungi Dayang Torek dari berbagai gangguan dan marabahaya, kesadaran untuk ikut bertanggung jawab merupakan jawaban untuk berbagai persoalan yang dihadapi oleh banyak keluarga di masa sekarang. Linggau menyadari bahwa salah satu tanggung jawabnya sebagai laki-laki adalah melindungi adik perempuannya Dayang Torek. Sebagaimana diceritakan, kecantikan Dayang Torek menyebabkan banyak pemuda yang terpikat serta berniat mempersuntinya, termasuk Si Pahit Lidah. Berbagai cara ditempuh oleh para pemuda tersebut agar dapat memperistri Dayang Torek, baik cara-cara yang dibenarkan oleh adat dan norma yang berlaku, maupun cara-cara yang lebih didasarkan oleh ambisi dan keserakahan semata. Kondisi itu pula yang menyebabkan Linggau terpaksa melakukan berbagai cara dalam upaya melindungi Dayang Torek, bahkan sampai membuat lobang di dasar sungai yang akan dijadikan sebagai tempat persembunyian Dayang Torek.

\section{Silampari : Mitos Kerajaan Ulak Lebar}

Cerita berasal dari sebuah negeri di kaki Bukit Sulap, kebanggaan masyarakat Lubuklinggau sampai zaman sekarang. Di kaki Bukit Sulap, dari arah Barat Laut ke Selatan mengalir Sungai Kasie dan Sungai Ketue. Kedua sungai tersebut bermuara di Sungai Kelingi. Negeri tersebut kemudian menjadi Kerajaan Ulak Lebar serta diperintah oleh Raja Biku. Memiliki kebiasaan sebagai pengembara sakti, Raja Biku bergelar "Delapan Dewa. Raja Biku menguasai ilmu kesaktian yang dimiliki oleh delapan orang dewa. Isteri Raja Biku bernama Putri Ayu Selendang Kuning, seorang peri jelita dari alam dewata. Berstatus sebagai permaisuri Raja Biku, Putri Ayu Selendang Kuning adalah adik Dewa Mantra Guru Sakti Tujuh. Dewa Mantra dipercaya sebagai utusan kayangan—penjaga Ulak Lebar serta negeri-negeri di sekitarnya.

Raja Biku tidak memiliki keturunan meskipun telah sepuluh tahun berkeluarga dan memerintah di Kerajaan Ulak Lebar. Rakyat Ulak Lebar hidup damai dan sejahtera. Mereka 
memiliki raja yang memerintah dengan adil dan bijaksana. Sebaliknya, kegelisahan istana beserta seluruh rakyat Ulak Lebar terus menguat, siapa kiranya yang akan mewarisi tahta Raja Biku kelak. Waktu terus berjalan dan Raja Biku kemudian mengadukan kegelisahannya kepada Dewa Mantra Guru Tujuh. Raja Biku dan Putri Ayu Selendang Kuning, setelah menjalankan pertapaan di Bukit Alas Rimba, pada gilirannya beroleh kabar gembira tentang kelahiran anak-anak mereka. Raja Biku akhirnya memiliki keturunan setelah menuruti arahan Dewa Mantra Guru Tujuh. Enam anak Raja Biku, mereka adalah mu'jizat dari alam dewata, terlahir karena keramat kembang tujuh dari kayangan. Mereka adalah, sang putra mahkota yang diberi nama Sebubur, Dayang Torek, Dayang Jeruju, Dayang Teriji, Dayang Ayu dan Dayang Iring Manis.

Di antara kelima putri Raja Biku, Dayang Torek dikenal sebagai putri raja yang paling cantik. Kecantikan Dayang Torek terkenal ke seantero negeri sehingga kepadanya dilekatkan sebutan "bak peri dari kayangan". Banyak raja dan pangeran yang berhasrat untuk mempersunting Dayang Torek. Di lain pihak, Sebubur sebagai satu-satunya saudara laki-laki dalam keluarganya terus bertumbuh menjadi seorang pengembara sakti. Dia menimba banyak ilmu kesaktian sebagai persiapan sebelum mewarisi tahta Kerajaan Ulak Lebar. Karenanya Sebubur acap kali meninggalkan kerajaan. Dia mengembara dari satu negeri ke negeri lain. Menjalani pertapaan secara berulang, berpindah dari satu tempat ke tempat yang lain, sekaligus menjadi ritual Sebubur dalam memperdalam ilmu kesaktian yang dimiliki.

Sultan Palembang adalah seorang raja yang sangat menginginkan untuk mempersunting Dayang Torek. Sang sultan kemudian mengirim utusan ke Ulak Lebar dengan maksud meminang Dayang Torek. Prosesi pinangan tersebut bertepatan dengan kepergian Raja Biku ke Negeri Cina sekaligus perjalanan Sebubur untuk menyusul ayahanda tercinta. Keluarga istana mengalami kepanikan atas pinangan Sultan Palembang. Dayang Torek menolak pinangan tersebut dan penolakan itulah yang kemudian menjadi pangkal permasalahan yang dihadapi Kerajaan Ulak Lebar. Sultan Palembang merasa tersinggung atas penolakan Dayang Torek serta memutuskan untuk menculiknya dengan menggunakan tangan Raden Bintang. Kerajaan Ulak Lebar merasa terhina dan berduka secara mendalam atas kejadian tersebut.

Lama berlalu, Sebubur pun kembali dari perjalanan panjangnya menyusul keberangkatan Raja Biku. Dia kembali ke Ulak Lebar dengan tangan hampa karena tidak mampu membawa serta Raja Biku. Sang Raja Ulak Lebar telah silam ke dasar Laut Cina Selatan, memenuhi takdirnya sebagaimana disampaikan dulu oleh Dewa Mantra Raja Tujuh. Sebubur memutuskan untuk menjemput Dayang Torek ke Kesultanan Palembang. Bermodalkan ilmu kesaktian yang 
tinggi Sebubur akhirnya mampu membawa pulang Dayang Torek yang ternyata telah memiliki seorang bayi, keturunan Raja Pelambang.

Perjalanan pulang Sebubur beserta Dayang Torek ditandai oleh peristiwa tragis meninggalnya bayi Dayang torek di Tangan Sebubur. Bayi tersebut dibunuh karena dianggap akan membawa aib terhadap Kerajaan Ulak Lebar. Dayang Torek tidak menerima kenyataan pahit tersebut. Dayang Torek kemudian memutuskan untuk silam ke alam dewata serta membawa serta bayinya yang telah meninggal dunia. Peristiwa magis silamnya Dayang Torek terjadi di puncak Bukit Sulap. Sebubur tidak berdaya untuk mencegah takdir Dayang Torek. Saudara perempuan yang sangat disayanginya itu memenuhi takdir sebagaimana telah digariskan oleh Dewa Mantra Guru Tujuh sejak dahulu kala.

Sebubur, pengembara sakti sekaligus putra mahkota Kerajaan Ulak Lebar, adalah tokoh penting dalam legenda Silampari. Perannya dalam cerita menandai silamnya seluruh anggota keluarga istana. Raja Biku yang memenuhi takdir dan silam ke dasar laut Cina Selatan, Putri Ayu Selendang Kuning beserta kelima saudara perempuan Sebubur-salah seorangnya adalah Dayang Torek, silam kembali ke alam dewata. Bahkan Sebubur kemudian juga tidak bisa menolak takdir. Dia juga ikut silam, meninggalkan Kerajaan Ulak Lebar dan kembali ke alam dewata.

Silampari, begitulah lidah orang Lubuklinggau yang hidup setelah masa Sebubur dan Kerajaan Ulak Lebar. Sebubur beserta seluruh anggota keluarganya meninggalkan alam dunia dan kembali ke alam dewata. Secara terminologi kata silampari bermakna "peri" yang "silam" dan memang demikian makna yang disematkan oleh orang Lubuklinggau hingga masa sekarang.

\section{Refleksi Kearifan Lokal}

Ditulis dalam cerita "Silampari : Mitos Kerajaan Ulak Lebar", Sebubur merupakan seorang pengembara sakti sekaligus putra mahkota Kerajaan Ulak Lebar. Dia adalah tokoh penting dalam cerita legenda ini. Perannya dalam cerita menandai silamnya (hilang-raib) seluruh anggota keluarga istana. Raja Biku yang memenuhi takdirnya dan akhirnya silam ke dasar laut Cina selatan, Putri Ayu Selendang Kuning beserta kelima saudara perempuan Sebubur-salah seorangnya adalah Dayang Torek, silam kembali ke alam dewata. Bahkan Sebubur kemudian juga tidak bisa menolak takdir. Dia juga ikut silam, meninggalkan Kerajaan Ulak Lebar dan kembali ke alam dewata. Silampari, begitulah lidah orang Lubuklinggau yang hidup setelah masa Sebubur dan Kerajaan Ulak Lebar menyebut peristiwa demi peristiwa magis tersebut. 
Sebubur beserta seluruh anggota keluarganya meninggalkan alam dunia dan kembali ke alam dewata.

Kearifan lokal pertama yang mesti diwarisi oleh masyarakat Lubuklinggau dari cerita “Silampari : Mitos Kerajaan Ulak Lebar", terutama berkaitan dengan sikap dan perilaku muliya yang harus diwarisi adalah, sabar dan tidak berputus asa. Sikap sabar serta tidak berputus asa tersebut dicontohkan oleh Raja Biku bersama permaisurinya Putri Ayu Selendang Kuning. Kesabaran yang berbuah manis, penguasa Kerajaan Ulak Lebar itu dikaruniai beberapa orang anak setelah sekian lama mendambakan keturunan. Tentunya warisan kearifan lokal ini tidak hanya diperuntukkan kepada pasangan suami istri yang sulit memperoleh keturunan serta pada konteks kekinian masyarakat Lubuklinggau tengah berkuasa, misalnya tengah menduduki satu jabatan penting dalam jajaran pemerintah daerah. Pelajaran tentang kesabaran serta tidak berputus asa, sebagaimana dicontohkan Raja Biku dan Putri Ayu Selendang Kuning, perlu tertanam dalam sikap dan perilaku setiap pasangan suami istri di Lubuklinggau. Tidak hanya terkait dengan harapan serta upaya untuk memperoleh keturunan, kesabaran serta sikap tidak berputus asa, mesti mewarnai setiap aktifitas keluarga di Lubuklinggau.

Sejarah membuktikan bahwa kesabaran yang diiringi oleh kesungguhan dalam berusaha serta tidak berputus asa ketika belum berhasil senantiasa berbuah manis. Kesabaran itu pula yang mesti ditopang oleh keyakinan yang kuat kepada adanya kekuatan serta kekuasaan yang melampai setiap kuasa yang dimiliki oleh manusia. Kesabaran Raja Biku beserta Putri Ayu Selendang Kuning yang ditopang oleh keyakinan bahwa mereka akan berhasil bahkan telah mengantarkan Kerajaan Ulak Lebar mencapai kejayaannya. Rakyat Kerajaan Ulak Lebar hidup penuh suka cita di bawah kepemimpinan Raja Biku yang bijaksana serta mampu menempatkan segala upaya kepemimpinannya sebagai seorang penguasa dalam rangka menguatkan keyakinan religiusitasnya kepada kuasa di atas kuasanya sebagai manusia biasa.

Kedua, cerita "Silampari : Mitos Kerajaan Ulak Lebar", juga mengajarkan pentingnya sikap rendah hati penguasa. Seperti dilekatkan pada watak tokoh Sultan Palembang, ketamakan serta upaya memaksakan kehendak untuk mempersunting Dayang Torek telah menjadi perilaku buruk penguasa yang pada gilirannya berdampak buruk pada banyak pihak. Tidak hanya menimpa Dayang Torek secara pribadi, ketamakan Sultan Palembang juga menimbulkan aib dan duka mendalam bagi keluarga rakyat Kerajaan Ulak Lebar. Nafsu kekuasaan Sultan Palembang, digambarkan dalam bentuk sikap yang cenderung beristeri lebih dari satu orang, telah berimbas pada rusaknya tatanan nilai sosial budaya masyarakat pada zaman itu. Masyarakat dipertontonkan 
serta diajak untuk menyaksikan perilaku buruk penguasa dan sikap itulah yang harus dihindarkan oleh para penguasa Lubuklinggau masa sekarang. Mereka yang diberi amanah memegang satu jabatan dalam jajaran Pemerintah Daerah Lubuklinggau mesti mengutamakan sikap rendah hati dalam memanfaatkan berbagai fasilitas yang ada. Para pejabat pemerintah di Lubuklinggau harus mampu menjadi suri tauladan yang baik untuk segenap lapisan masyarakat, termasuk dalam hal pemenuhan kebutuhan beristeri dan berkeluarga.

Ketiga, kearifan lokal cerita “Silampari : Mitor Kerajaan Ulak Lebar” adalah proporsional. Sikap proporsional menjadi teramat penting ketika seseorang berhadapan dengan satu permasalahan yang terkait dengan banyak pihak. Tidak proporsional dalam bertindak dan mengambil satu keputusan hanya akan mengakibatkan adanya pihak-pihak yang merasa dikecewakan. Didalam cerita, sikap proporsional itulah yang tidak dimiliki Sebubur, yaitu ketika harus mengambil sikap terkait dengan kasus penculikan Dayang Torek oleh Sultan Palembang. Sebubur dikuasai oleh emosi dan dendam karena kesewenang-wenangan Sultan Palembang. Sebubur tidak terima dengan pilihan sikap Sultan Palembang ketika menculik Dayang Torek. Akibatnya, Sebubur menempuh cara-cara penyelesaian permasalahan secara tidak proporsional, yaitu menculik kembali Dayang Torek dari Kesultanan Palembang. Dayang Torek telah diperistri oleh Sultan Palembang serta telah memiliki seorang anak. Sebubur tidak proporsional, terlihat dari upayanya membawa pulang Dayang Torek ke Kerajaan Ulak Lebar. Lebih buruk lagi, Sebubur membunuh bayi yang tidak berdosa, buah dari perkawinan Dayang Torek dengan Sultan Palembang.

Sikap proporsional pada gilirannya akan mampu membentengi setiap orang untuk tidak terjerumus melakukan hal-hal yang tidak rasional. Sikap proporsional itu pula yang tidak dimiliki oleh Sebubur, tokoh legenda cerita "Silampari : Mitos Kerajaan Ulak Lebar". Pelajaran pentingnya adalah, masyakat Lubuklinggau pemilik cerita rakyat ini mesti memiliki kematangan dalam berpikir serta bersikap, yang pada gilirannya mendorong munculnya perilaku proporsionalitas. Masyarakat Lubuklinggau mesti mewarisi sikap peduli dan tanggung jawab terhadap keluarga dan kerajaan sebagaimana dicontohkan Sebubur. Dia sangat menyayangi adik perempuannya Dayang Torek, karena itu ingin melindunginya meskipun harus mengorbankan nyawa. Penculikan Sultan Palembang terhadap dayang Torek dianggap telah menghina serta menciderai kehormatan Kerajaan Ulak Lebar. Sebubur adalah putra mahkota kerajaan dan harus berbuat untuk mengembalikan kehormatan kerajaan yang dilecehkan. 
Namun demikian, sikap tidak proporsional sebagaimana juga dicontohkan Sebubur dalam mengambil keputusan, mesti pula dihindarkan. Sebubur menempuh cara-cara yang sama sebagaimana dilakukan oleh Sultan Palembang. Dia terjebak oleh rasa sakit hati dan dendam kesumat kepada Sultan Palembang yang dianggap telah menciderai kehormatan Kerajaan Ulak Lebar. Sebubur melupakan keterlibatan Dewa Mantra Guru Sakti Tujuh—tokoh gaib alam dewata yang dikenalkan secara implisit dalam cerita—dalam setiap kejadian yang menimpa keluarganya dan kerajaan Ulak Lebar pada umumnya. Lebih buruk lagi, Sebubur tidak mampu melihat persoalan secara jernih, sehingga menimpakan kesalahan pada pihak-pihak yang semestinya tidak terlibat. Sebubur membunuh bayi yang tidak berdosa; korban paling menyedihkan dalam cerita "Silampari : Mitos Kerajaan Ulak Lebar". Bayi Dayang Torek itu tidak "silam" ke alam dewata, sebagaimana dialami oleh anggota keluarga Kerajaan Ulak Lebar lainnya. Bayi tidak berdosa, buah perkawinan Dayang Torek dengan Sultan Palembang, meninggal secara menyedihkan sebagai akibat tidak proporsionalnya Sebubur-putra mahkota Kerajaan Ulak Lebar dalam bersikap dan mengambil keputusan

\section{Bujang Kurab : Pengembara Sakti yang Budiman}

Bujang Kurap, biasa juga dikenal dengan nama Embun Semibar, tokoh legendaris Lubuklinggau. Bujang Kurap terkenal sakti diseantero negeri, khususnya pada beberapa negeri di sekitar Bukit Sulap Lubuklinggau. Meskipun memiliki tubuh yang penuh dengan kurap dia tidak pernah putus asa dalam memperjuangkan keadilan dan kebenaran. Pengembaraannya di banyak negeri selalu meninggalkan cerita tentang kepahlawanan serta keramahannya dalam bergaul. Dia senang menolong orang yang berada dalam kesusahan serta senantiasa menjauhkan diri dari sifat sombong. Kesaktian yang dimiliki Bujang Kurap mendatangkan manfaat bagi banyak orang.

Bujang Kurap dilahirkan di daerah Melayu Bangko, Sarolangun Jambi. Bujang Kurap berasal dari keluarga elit tradisional menurut garis keturunan Datuk Saribijaya yang mempersunting Putri Sari Banilai. Dt. Saribijaya berasal dari Kerajaan Pagaruyung Minangkabau. Oleh karena itu, tidaklah heran bila Bujang Kurap terus tumbuh menjadi remaja yang berkepribadian luhur. Bujang Kurap sangat suka menuntut ilmu, baik ilmu kemasyarakatan dan terlebih lagi ilmu kesaktian.

Sedari kecil penyakit kurap telah diderita Bujang Kurap. Meskipun tidak berada di sekujur tubuhnya, namun penyakit tersebut seakan telah menjadi bagian dari takdir hidup Bujang Kurap. Pada mulanya penyakit kulit tersebut sangat mengganggu pergaulan Bujang Kurap. Dia merasa 
enggan untuk bergaul dengan masyarakat. Dia takut kehadirannya di tengah masyarakat hanya akan membuat resah dan ketakutan.

Nama Embun Semibar lekat di diri Bujang Kurap setelah menyelesaikan pertapaan panjang guna memeperdalam ilmu kesaktian. Nama tersebut merupakan pemberian gaib yang diterima Bujang Kurap setelah berhasil dengan tapanya. Bujang Kurap telah memiliki kesaktian yang tinggi dan semenjak itu penyakit Kurap betul-betul memenuhi sekujur tubuhnya.

Salah satu kesaktian Bujang Kurap adalah kemampuannya berubah rupa. Bujang Kurap bisa berubah menjadi apapun yang dia inginkan. Meskipun demikian, ilmu berubah rupa tidak pernah digunakannya untuk kejahatan. Di samping mampu berubah rupa, kurap di tubuh Bujang Kurap adalah senjata ampuh yang pada saat-saat tertentu digunakannya untuk mengalahkan musuh. Kelupas kurap Bujang Kurap akan berubah menjadi besi baja yang tajam serta sangat mumpuni untuk membunuh-lawan-lawannya. Tidak jarang Bujang Kurap terpaksa menggunakan lempeng-lempeng baja yang berasal dari kurap yang dia derita. Lawan sakti yang mesti dia hadapi pada satu waktu memaksa Bujang Kurab menggunakan lempeng baja yang berasal dari kelupas kulitnya karena penyakit kurab yang diderita.

Bujang Kurap mengembara dari satu negeri ke negeri lain, dari satu kerajaan ke kerajaan lain. Buruk rupa, senantiasa dibenci dan dicaci, namun tidak pernah berhenti menebar kebaikan. Setiap singgah di suatu negeri Bujang Kurap selalu meninggalkan cerita baik. Orang-orang yang ditinggalkan akan selalu mengenang pertolongan Bujang Kurap. Mereka berhutang budi karena biasanya tidak akan sempat membalas jasa. Berterima kasih pun kadang tidak sempat. Setelah memberikan pertolongan Bujang Kurap lebih memilih untuk pergi secara gaib sehingga tidak diketahui oleh orang. Itulah Bujang Kurap, penebar kebaikan tanpa berharap adanya balasan dari orang-orang yang ditolong.

Dalam pengembaraan panjangnya Bujang Kurap menimba banyak pengalaman dan ilmu yang bermanfaat. Ilmu kesaktiannya semakin mumpuni dan tidak terkalahkan. Bujang Kurap pun bertemu dengan banyak pendekar sakti dalam perjalanannya menumpas kejahatan. Diusia tuanya kelak, segala ilmu dan pengalaman yang dimiliki dipraktekkan dalam pengabdiannya kepada masyarakat. Di Ulak Lebar, sebuah negeri yang terletak di lembah Bukit Sulap Lubuklinggau, di daerah inilah Bujang Kurap menghabiskan masa tuanya. Masyarakat Ulak Lebar menerima Bujang Kurap apa adanya. Buruk Rupa yang dimiliki Bujang Kurap tidaklah penting bagi penduduk Ulak Lebar karena yang mereka butuhkan adalah pengalaman dan ilmu Bujang Kurap. Bujang Kurap adalah tokoh pengembara rendah hati. Meskipun berilmu tinggi Bujang Kurap tetaplah rendah hati. 
Di kawasan Negeri Ulak Lebar, sebuah kawasan yang subur di kaki Bukit Sulap, Bujang Kurap menyudahi pengembaraannya. Lingkungan alam ulak Lebar sangatlah strategis. Kawasan ini dibentuk oleh tiga aliran sungai, yaitu Sungai Kesia, sungai Katie dan sungai Kelingi. Di kawasan inilah sekarang terdapat menhir-menhir yang berjajar sebagai buah peradaban megelitikum. Menhir-menhir itu adalah adalah bukti pekuburan para kaum elit tradisional masyarakat Negeri Ulak Lebar pada zaman dahulu.

Di antara makam para pemimpin Negeri Ulak Lebar, tepatnya di tepi Sungi Kelingi dan sebelah Selatan Benteng Kuto Ulak Lebar, terdapat sebuah kuburan yang diberi tanda berupa sepasang megalitik. Masyarakat Lubuklinggau sekarang percaya bahwa ituah tempat persemayaman jasad Bujang Kurap atau Embun Semibar. Hingga sekarang kuburan Bujang Kurap masih dianggap keramat, terutama oleh keturunan penduduk asli ulak Lebar. Masih dapat ditemukan peninggalan para peziarah setelah melakukan ritual di sekitar makam Bujang Kurap, seperti sisa sabut kelapa, piring kaleng dan lain sebagainya. Mereka percaya bahwa lokasi makam Bujang Kurap adalah tempat keramat yang tepat untuk dijadikan lokasi pelaksanaan ritual magis untuk tujuan kebaikan kehidupan di masa sekarang.

\section{Refleksi Kearifan Lokal}

Pelajaran penting layak dipetik dari cerita "Bujang Kurap : Pengembara Sakti yang Budiman", sebagai kearifan lokal masyarakat Lubuklinggau tempo dulu. Kearifan lokal tersebut penting untuk direnungkan ulang serta diwarisi oleh masyarakat Lubuklinggau di masa sekarang. Bujang Kurap, tokoh legenda dalam cerita merupakan pendekar sakti mandraguna serta dikenal budiman karena memiliki budi pekerti yang mulia. Bujang Kurap, khususnya oleh penduduk pada beberapa negeri di sekitar Bukit Sulap Lubuklinggau, merupakan figur pengembara sakti yang berhasil mengabdikan hidupnya untuk kemaslahatan orang banyak. Meskipun memiliki tubuh yang penuh dengan kurap dia tidak pernah berhenti memperjuangkan nilai-nilai keadilan dan kebenaran. Pengembaraannya di banyak negeri selalu meninggalkan cerita tentang kepahlawanan, keramahan serta kerendahan hatinya dalam bergaul. Tidak jarang Bujang Kurap menjadi bulan-bulanan karena penyakit kulit yang diderita, namun semua disikapi dengan penuh kebijaksanaan.

Bujang Kurap senantiasa membalas keburukan dengan kebaikan. Dia senang menolong orang yang berada dalam kesusahan serta senantiasa menjauhkan diri dari sifat sombong. Kesaktian yang dimiliki Bujang Kurap mendatangkan manfaat bagi banyak orang. Bahkan, tidak jarang Bujang Kurap justru berhadapan dengan penguasa yang zalim dalam mewujudkan 
tujuan-tujuannya. Berbekal kesaktian yang dimiliki serta pengetahuan yang luas tentang banyak hal Bujang Kurap mampu mematahkan segala bentuk kesewenang-wenangan pengusa. Oleh karena itu, banyak orang berhutang budi bahkan nyawa kepada Bujang Kurap. Namun yang menarik, tidak sekalipun Bujang Kurab menuntut untuk harus pula menerima kebaikan dari orang-orang yang ditolong. Berbuat tampa pamrih serta menolong tamba berharap balasan, itulah tipikal budiman Bujang Kurap dalam menguatkan figurnya sebagai tokoh masyarakat yang dicintai banyak orang.

Karakter muliya Bujang Kurap merupakan tauladan kepribadian yang harus diwarisi oleh masyarakat Lubuklinggau, khususnya oleh generasi muda. Ilmu kesaktian yang dimiliki tidak menjadikan Bujang Kurap terjerumus pada perilaku angkuh dan sombong. Sebaliknya, penyakit kulit yang diderita tidak menjadikan Bujang Kurap berputus asa dalam menebar kebaikan. Sakti mandraguna yang pada konteks sekarang dapat didefinisikan ulang memiliki pengetahuan yang luas tidak menyebabkan Bujang Kurap berperilaku culas dan semena-mena. Penyakit pun tidak merobah Bujang Kurap menjadi introver serta menempuh cara-cara terkeji dalam mencapai berbagai tjuan hidupnya. Bujang Kurap mampu besalik rupa (berubah wujud) menjadi apapun yang dia inginkan. Meskipun demikian, ilmu tersebut tidak pernah digunakannya untuk kejahatan. Bujang Kurap memang si buruk rupa, senantiasa dihina, dibenci dan dicaci, namun tetap tabah serta tidak pernah berhenti berbuat baik bahkan kepada orang-orang yang menghinanya.

Belajar dari cerita Bujang Kurap serta berupaya mengidealisasi kearifan lokal tokoh masyarakat Lubuklinggau tempo dulu kiranya menjadi alternatif dalam melahirkan figur-figur baru di tengah masyarakat Lubuklinggau masa sekarang. Buruk rupa bukanlah segalanya dan berilmu tinggi tidaklah pula harus menjadikan seseorang menjadi pongah dan sombong. Keterbatasan fisik sesungguhnya bisa dikemas menjadi potensi sehingga mampu mendatangkan kebaikan minimal untuk diri sendiri. Berilmu tinggi tentunya adalah kelebihan yang mesti dipergunakan untuk mencapai berbagai tujuan muliya dalam kehidupan masyarakat luas. Oleh karena itu, pesan lainnya dari cerita Bujang Kurap adalah memaksimalkan upaya dalam menempa potensi diri, sekaligus tidak terpaku oleh berbagai keterbatasan fisik yang memang telah ditakdirkan oleh Yang Maha Kuasa.

Hingga masa sekarang kuburan Bujang Kurap masih dianggap keramat, terutama oleh keturunan penduduk asli Ulak Lebar. Makam Bujang Kurap senantiasa diziarahi dan kebaikannnya serta dikenang dan diperbincangkan ulang. Karena itu, masyarakat Lubuklinggau zaman sekarang, khususnya para generasi muda, mesti menjadi Bujang Kurap dalam pengertian 
penebar kebaikan kepada masyarakat. Generasi muda mesti memiliki kesungguhan dalam menuntut ilmu pengetahuan serta kemudian mendarmabaktikannya untuk kemaslahatan orang banyak. Kalaupun memiliki keterbatasan fisik maka sikapilah dengan bijaksana. Segala keterbatasan tersebut sejatinya tidak menjadi hembatan yang bersifat terus-menerus untuk menjadi orang baik dan berguna. Gali potensi diri, perkaya mental dengan pengetahuan serta berperan aktiflah dalam pembangunan Kota Lubuklinggau yang terus berbenah.

\section{PENUTUP}

Melalui tulisan yang berfokus menemukenali kearifan lokal pada cerita rakyat Lubuklinggau disimpulkan sebagai berikut :

Pertama, cerita rakyat Lubuklinggau dimaksud adalah, cerita Linggau dan Dayang Torek : Asal Mula Kota Lubuklinggau, cerita Silampari : Mitos Kerajaan Ulak Lebar, dan cerita Bujang Kurap : Pengembara Sakti yang Budiman. Berdasarkan analisis, kearifan lokal cerita rakyat tersebut berkaitan dengan nilai-nilai kebaikan dan kebijaksanaan serta sebaliknya keburukan yang dikenali melalui tema, tokoh dan penokohan serta pesan moral yang secara implisit dihadirkan dalam cerita. Kedua, kearifan lokal dimaksud sebagiannya merupakan nilai-nilai yang seyogianya diwarisi oleh masyarakat Lubuklinggau dan sebagiannya mesti ditolak serta dihindarkan. Kearifan lokal yang mesti diwarisi di antaranya, kesabaran, kesungguhan dalam belajar dan menuntut ilmu, tanggung jawab, tidak berputus asa, membalas keburukan dengan kebaikan, berkontribusi terhadap lingkungan, patuh terhadap ketentuan hukum dan norma, sederhana serta mendahulukan kepentingan masyarakat dibandingkan kepentingan pribadi dan keluarga. Sementara itu, nilai-nilai keburukan yang mesti ditolak serta dihindarkan adalah, kesewenang-wenangan, ketamakan, egois, persekongkolan jahat, berbohong dan emosional.

Penting dilakukan kajian lanjutan terhadap cerita rakyat Lubuklinggau, dalam bentuk dokumentasi dan analisis teks cerita, khususnya dilakukan terhadap cerita rakyat yang belum berhasil didokumentasi. Kegiatan pengkajian yang bersifat berkelanjutan serta dilakukan dengan pendekatan keilmuan yang relefan dinilai sebagai bagian dari upaya mengantisipasi agar tidak terkondisinya cerita rakyat dimaksud beserta kearifan lokal yang terdapat dalam cerita terkonisi menuju kepunahan terutama di kehidupan generasi muda Lubuklinggau. Masyarakat Lubuklinggau, khususnya para maestro dibantu oleh jajaran pemerintah daerah Kota Lubuklinggau, kiranya perlu memikirkan berbagai langkah strategis dalam upaya memperkenalkan setiap cerita kepada generasi muda. Kemasan cerita yang lebih apik dan 
menarik — setelah didokumentasi dari masyarakat, kemudian disajikan dalam kurikulum muatan lokal yang diajarkan di sekolah, merupakan salah satu langkah yang bisa ditempuh. Selanjutnya perlu pula dipikirkan cara dan metode yang tepat dalam mewariskan kearifan lokal cerita, misalnya dengan meningkatkan intensitas diskusi dan dialog dengan menghadirman para maestro cerita sebagai narasumber dan para peserta didik dari berbagai jenjang pendidikan sebagai peserta aktif.

Menjadi tanggung jawab pemerintah daerah Kota Lubuklinggau untuk terus mendorong serta menyiapkan berbagai fasilitas yang dibutuhkan oleh masyarakat lokal dalam usaha melestarian khasanah budaya, termasuk di dalamnya cerita rakyat. Pemerintah daerah Kota Lubuklinggau bersama tokoh masyarakat lokal serta para maestro kebudayaan mesti terus meningkatkan bentuk-bentuk apresiasi yang diberikan kepada masyarakat Lubuklinggau, baik dalam aspek kuantitas maupun dalam aspek kualitas. Masyarakat Lubuklinggau "sadar budaya" mesti terwujud dan terus menguat, khususnya dalam rangka menginternalisasikan kearifan lokal yang terdapat dalam berbagai khasanah budaya yang dimiliki.

\section{DAFTAR PUSTAKA}

Badan Pusat Statistik Kota Lubuklinggau Tahun 2015

Danandjaja, James.1984. Pendekatan Foklor dan Penelitian Bahan-bahan Tradisi: Metodologi Kajian Tradisi Lisan. Jakarta: Yayasan Obor Indonesia. 1991. Folklor Indonesia : Ilmu Gosip, Dongeng dan Lain-lain. Jakarta : PT Pustaka Utama Grafiti.

Maleong, Lexy Y. 1989. Metodologi Penelitian Kualitiatif. Bandung : Remaja Rosdakarya.

Ratna, Nyoman Kutha. 2004. Teori, Metode, dan Teknik Penelitian Sastra. Yokyakarta : Pustaka Pelajar. Satori, Djam'an dkk. 2009. Metodologi Penelitian Kualitatif. Bandung : Alvabeta.

Sibarani, Robert. 2016. Pembentukan Karakter Berbasis Kearifan Lokal :kajian Multidisiplin Terhadap Tradisi Lisan. (Makalah Prosiding ATL 2016).

Jakarta ATL. Hal.

Wiranta, Sukarna. 2007. Analisis Data Kualitiatif. Modul Diklat Fungsional Peneliti Tingkat Pertama. Cibinong : Pusat Pembinaan, Pendidikan dan Pelatihan Peneliti LIPI.

\section{INTERNET}

https://id.wikipedia.org/wiki/Kota_Lubuklinggau 